\title{
Mediation in Duitsland: een diepgravend onderzoek in opdracht van de Duitse regering
}

\author{
Luc Demeyere
}

De Duitse Mediationwet van 21 juli 2012, gewijzigd bij wet van 31 augustus 2015 (MediationsG) en in werking getreden in 2012, bepaalde dat de Bondsregering uiterlijk op 26 juli 2017 een rapport aan de Bondsdag diende voor te leggen. Het Rapport van de Bondsregering over de effecten van de Mediationwet op de ontwikkeling van mediation in Duitsland en over de toestand van de vorming en voortgezette vorming van de mediators (Bericht zur Evaluierung des Mediationsgesetzes) dateert van juli 2017 en werd opgemaakt door het Deutsches Forschungsinstitut für öffentliche Verwaltung (www.foev-speyer.de; het rapport is op deze website gratis te downloaden; https://dopus.uni-speyer.de/frontdoor/deliver/index/ docId/3084/file/Abschlussbericht+Mediatonsgesetz+(2016-11).pdf), meer bepaald het Institut für Gesetzesfolgenabschätzung und Evaluation in opdracht van het Duitse ministerie van Justitie. Het rapport onderzoekt de resultaten van een bijzonder uitgebreide enquête en beslaat 215 bladzijden met weergave van de vragen en uitvoerig statistisch materiaal.

Meer dan duizend respondenten uit de Bondsrepubliek vulden de enquête in. Vastgesteld werd dat de mediationmarkt, in de zin van het aantal doorgevoerde mediations, stagneert. De respondenten voerden in 2014 circa 7110 mediations, in 2015 circa 8285 en in 2016 circa 7405. Dit resulteert voor 2016 in circa acht mediations per mediator.

Duitsland kent ook de Güterichter, hetgeen mag vertaald worden als 'verzoeningenrechter', en uit het sedert 2014 beschikbaar statistisch materiaal blijkt dat het aantal dossiers behandeld door de verzoeningenrechters slechts enkele procentpunten, of, naargelang het rechtsdomein, nog minder, bedraagt. De doorverwijziging naar de Güterichter ( $\$ 278,(5) \mathrm{ZPO})$ is nog te onderscheiden van de algemene opdracht van de Duitse rechters om een minnelijke regeling tussen de partijen te bevorderen $(\$ 278,(1) \mathrm{ZPO}) .^{1}$

\section{Bevinding 1: weinig mediations, erg ongelijk verdeeld over de mediators}

In 2016 heeft meer dan twee derde (67\%) van de respondenten minder dan vijf of zelfs geen mediations gevoerd (13\% überhaupt geen). $18 \%$ van de mediators behandelde tussen tien en twintig mediations per jaar en slechts $7 \%$ komt uit op meer dan twintig mediations.

1 Zie voor meer hierover: B. Hess, 'Mediation Judges' in Germany: Mutual Interference EU Standards and National Developments, in: C.H. van Rhee \& F. Yulin (red.), Civil Litigation in China and Europe, Dordrecht/Heidelberg/New York/London: Springer 2014, p. 185-194. 
Daaruit volgt dat mediation meestal als bijkomende activiteit (41\%) of enkel 'uitzonderlijk' (27\%), dit wil zeggen naast het eigenlijke beroep, wordt uitgeoefend. Voor driekwart van de respondenten (75\%) betekent mediation (beduidend) minder dan $25 \%$ van hun beroepsactiviteit. Enkel degenen die mediation als hoofdzakelijke beroepsactiviteit uitoefenen ( $17 \%$ van de respondenten) besteden een significant hoger aandeel van hun beroepsactiviteit aan mediation en voeren ook een beduidend hoger aantal mediations. $11 \%$ gaf te kennen in het verleden mediation meer, en thans 'enkel nog sporadisch' te voeren.

De belangrijkste beroepsgroepen die mediation als hoofdberoep of als nevenberoep uitoefenen, zijn consultants en coaches (42\%), evenals advocaten (20\%). Mediators zijn over het algemeen op meerdere domeinen actief, met name:

1 intern in ondernemingen en andere organisaties (administraties, ziekenhuizen, scholen, religieuze organisaties): $26 \%$ ondernemingen + circa $23 \%$ andere;

2 familie en gezin: $22 \%$; buurtgeschillen: $10 \%$;

3 commerciële bemiddeling (business-to-business): $12 \%$.

\section{Bevinding 2: beperkte inkomstenverwerving - aanzienlijk aandeel geïnvesteerd in vorming}

Slechts een beperkt aandeel van de mediators verwerft een belangrijk aandeel van zijn/haar inkomen uit de mediationactiviteit (meestal tussen 1 en $24 \%$ van het inkomen). Ook voor de groep die mediation als belangrijkste beroepsactiviteit heeft, vertegenwoordigt dit voor de meerderheid onder hen iets minder dan de helft van het inkomen. Uitsluitend deze laatste groep bereikt meestal een uurtarief van meer dan $€ 100$.

Vele mediators (ongeveer 25\%) zijn bedrijvig in de vorming en bijkomende vorming van mediators. Bij de groep voor wie mediation de belangrijkste beroepsactiviteit uitmaakt, bedraagt het aandeel van lesgevers 33\%. Voor deze groep maakt de vorming vaak een belangrijk aandeel van de beroepsactiviteit uit.

De grote meerderheid van de respondenten (80\%) volgde een door een federatie erkende of daarmee gelijkgestelde vorming. $13 \%$ voltooide een studierichting. Slechts 5\% van de 1090 respondenten, in antwoord op de vraag naar het aantal uren vorming, volgden minder dan 120 uur vorming. Als redenen om uit te maken wie als 'goede mediator' kan aanzien worden, worden hoofdzakelijk de 'houding' en de persoonlijkheid van de mediator aangestipt, de praktijkervaring en het aantal uren vorming daarentegen in beduidend geringere mate.

Een wijziging van de criteria voor de 'gecertificeerde mediator' zal in essentie uitwerking hebben op de markt voor de vorming van mediators. De 'klanten' zullen amper een gecertificeerde van een niet-gecertificeerde mediator kunnen onderscheiden (en helemaal niet wanneer er meerdere certificaten werden behaald). Deze vaststelling blijkt ook uit de interviews en workshops (zowel met vertegen- 
woordigers van federaties als met mediators) die werden gehouden. Belangstellenden die op doorverwijzing of aanbeveling mediation aanvragen, hebben geen belangstelling voor certificering.

\section{Bevinding 3: geen waarborg voor succes}

Alhoewel de bemiddeling zeer vaak in een overeenkomst resulteert, wil hiermee nog niet gezegd zijn dat ook het conflict kon worden beëindigd. Evenals bij de verzoeningenrechter is de waarschijnlijkheid van een conflictafhandeling door mediation circa 50\%. Het 'succes' van een mediation is bijgevolg eerder de uitzondering (conflict beëindigd: $42 \%$ 'zelden of niet', 34\% 'nu en dan', slechts $24 \%$ 'steeds' of 'duidelijk overwegend'). In circa $25 \%$ van de gevallen komt het minstens af en toe voor dat de mediation door een van de partijen wordt stopgezet.

\section{Bevinding 4: redenen voor het geringe aantal mediations - biedt bijkomende reglementering een uitkomst?}

De mediators zijn erg ontevreden over de "bekendheid van mediation bij de bevolking' (61\% ontevreden). Ook de concurrentie uitgaande van 'alternatieve aanbieders', zoals 'mediation per telefoon' aangeboden door de rechtsbijstandsverzekeraars, de verzoeningenrechter of andere aanbieders worden als negatief ervaren (60-48\%).

Het instrument dat met voorsprong het vaakst als positief ingeschat wordt om mediation te bevorderen is financiële tussenkomst bij mediation ( $86 \%$ van de respondenten). Evenwel kan ook een financiële tussenkomst voor mediation slechts moeilijk het probleem van de (vrijwillige) toestemming en bereidheid een mediation te voeren, oplossen. In de getalsmatig erg belangrijke domeinen van interne mediation binnen organisaties en van handelsmediation is het aspect van de financiële tussenkomst als instrument om het aantal mediations te beïnvloeden, verwaarloosbaar. In de domeinen van gezins-, familie- en buurtconflicten kan de vraag worden gesteld of een vermindering van de kosten ook de bereidheid tot een persoonlijke confrontatie met de tegenpartij verhoogt. Deze gevallen worden meestal gekenmerkt door emotioneel (erg) geëscaleerde conflicten, wat de bereidheid tot het bijleggen van het conflict in een persoonlijk gesprek verhindert onafhankelijk van de vraag wie de kosten ten laste neemt. Deze scepsis vindt steun in de resultaten van de juridische analyse. In de huidige stand van zaken is het af te raden onder komend recht een algemene ongedifferentieerde regeling tot financiële tussenkomst in te voeren.

Een bijzondere regeling tot uitvoerbaarverklaring van de overeenkomsten die het resultaat zijn van een mediation, hoeft niet. De in het toenmalige regeringsontwerp voorziene afzonderlijke procedure werd bij de parlementaire voorbereiding geschrapt, is niet gelijkwaardig aan een regeling tussen advocaten en het toepassingsgebied kan ondervangen worden door de bestaande wettelijke regelingen. 
De regelgeving met betrekking tot de vorming zoals voorzien in de toepasselijke Duitse verordening wordt gunstig onthaald. De vorming en permanente vorming van een mediator in Duitsland wordt geregeld door de 'Verordnung über die Ausund Fortbildung von zertifizierten Mediatoren' (Zertifizierte Mediatoren Ausbildungsverordnung; ZMediatAusbV) van 21 augustus 2016. Op voorwaarde dat een mediator een training en opvolging, die voldoet aan de wettelijk verplichte voorwaarden, heeft afgewerkt, is hij/zij gerechtigd zich 'zertifizierte(r) Mediator(in)' te noemen, zonder dat deze titel door een officiële instantie wordt toegekend. Alleszins zal, naar het oordeel van de respondenten, de titel 'gecertificeerde mediator' geen of slechts een zeer beperkte uitwerking op de aanvragen tot mediation hebben. Als voorwaarde voor het bereiken van positieve effecten is vereist dat transparantie en betrouwbaarheid van de certificering worden gecreëerd. In dit debat wordt een certificeringssysteem (van publiekrecht) als noodzakelijk aanzien, waardoor de naleving van kwaliteitsstandaarden betrouwbaar gevrijwaard wordt. Of hierdoor ook de verhoopte effecten zullen tot stand komen, kan evenwel niet empirisch bewezen worden. In voorkomend geval zullen de inspanningen die een dergelijk systeem vereisen, moeten afgewogen worden tegenover de eventueel te bereiken effecten.

\section{De resultaten van het onderzoek samengevat}

1 Het aantal doorgevoerde mediations stagneert op een gelijkblijvend beperkt aantal. De mediations concentreren zich daarbij overwegend bij een beperkt aantal mediators.

2 De mediationactiviteit biedt slechts geringe mogelijkheden tot inkomstenverwerving. Veel mediators zijn actief in de vorming.

3 Alhoewel de mediators de financiële tussenkomst voor mediation als het beste instrument ter bevordering van mediation aanzien, raadt het rapport af, alleszins op dit ogenblik, een algemene ongedifferentieerde regeling tot financiële bijstand in te voeren.

4 De uitvoerbaarverklaring van overeenkomsten resulterend uit mediations worden door de mediators slechts in zeer geringe mate als een instrument ter bevordering van mediation aanzien. Het rapport ziet ook geen behoefte aan een afzonderlijke regeling tot uitvoerbaarverklaring van overeenkomsten die het resultaat zijn van een mediation.

5 De certificering van mediators, zoals die op dit ogenblik uitgewerkt is, is weinig relevant voor de gebruikers. In welke mate een uniform publiekrechtelijk systeem tot certificering dit zou kunnen beïnvloeden, is empirisch niet bewijsbaar. 